\title{
An update from the 2019 ASCO Annual Meeting
}

\author{
Rupert Bartsch (iD
}

Received: 29 October 2019 / Accepted: 29 October 2019

(C) Springer-Verlag GmbH Austria, part of Springer Nature 2019

For decades, the American Society of Clinical Oncology (ASCO) Annual Meeting has been regarded as the most eminent oncology congress and a multitude of practice-changing trials reported their results at this meeting. While this has somewhat changed just recently with the European Society of Medical Oncology (ESMO) conference gaining relevance, news from the ASCO Annual Meeting is still of great clinical importance as outlined in this series of short reviews.

There is no doubt that non-small cell lung cancer (NSCLC) has been one of the most dynamic fields in oncology in recent years due to the great successes achieved with the introduction of immunotherapy concepts. The 2019 focus, however, was not on checkpoint inhibitors, but on the equally important areas of NSCLC genetics and novel small molecule drugs targeting rare and/or hard-to-target mutations and other genetic alterations as outlined by Romana Wass [1]. In contrast, no major advances in small cell lung cancer were reported, but Mircea Dediu did a great job in summarizing potentially relevant news [2].

Not surprisingly, three articles in this series are focusing on breast cancer. The article by Semir Beslija focuses on news concerning the (neo)adjuvant therapy in HER2-negative/hormone-receptor-positive breast cancer and summarizes information on prognostic and predictive biomarkers; in addition, the highly relevant-and much debated-question of extended adjuvant endocrine therapy is discussed [3].

In HER2-positive breast cancer, Marija Balic summarizes data on the potential role of neoadjuvant T-DM1 and presents novel evidence in two further

\footnotetext{
R. Bartsch $(\bowtie)$

Department of Medicine I, Division of Oncology, and Comprehensive Cancer Center, Medical University of Vienna, Waehringer Guertel 18-20, 1090 Vienna, Austria rupert.bartsch@meduniwien.ac.at
}

highly relevant fields: HER2 heterogeneity and its predictive role in patients receiving neoadjuvant therapy and treatment de-escalation. Indeed, the excellent survival results seen today in HER2-positive early stage breast cancer lead to the question if all patients require full-course standard chemotherapy [4]. Therefore, de-escalation is currently one of the great challenges in breast oncology. Finally, the last article focuses on new-and potentially clinically relevant-data from HER2-positive metastatic breast cancer [5].

Conflict of interest R. Bartsch declares that he has no competing interests.

\section{References}

1. Wass RE, Lang D, Lamprecht B, Studnicka M. Targeted therapy in lung cancer - ASCO 2019 update. memo. 2019. https://doi.org/10.1007/s12254-019-00538-3.

2. Dediu M. Current trends in small cell lung cancer management -ASCO 2019 update. memo. 2019. https://doi.org/ 10.1007/s12254-019-00539-2.

3. Beslija S. ASCO 2019 - Personal highlights on adjuvant breast cancer: (neo-)adjuvant therapy of HER2-negative HR-positive BC. memo. 2019. https://doi.org/10.1007/ s12254-019-00546-3.

4. Suppan C, Balic M. Adjuvant breast cancer: (neo)adjuvant therapy for HER2-positive breast cancer. The best of ASCO 2019. memo. 2019. https://doi.org/10.1007/s12254-01900530-x.

5. Bartsch R, Bergen E. ASCO 2019: highlights in HER2positive metastatic breast cancer. memo. 2019. https://doi. org/10.1007/s12254-019-00543-6.

Publisher's Note Springer Nature remains neutral with regard to jurisdictional claims in published maps and institutional affiliations. 